\begin{tabular}{|c|c|c|}
\multicolumn{3}{|c|}{ Article History } \\
\hline Submission: & Review: & Accepted: \\
15-08-2019 & $16-08-2019$ & $19-07-2019$ \\
& Doi: $\underline{\text { https://doi.org/10.33367/jiies.v2i1.882 }}$ & \\
\hline
\end{tabular}

\title{
Peran Dosen Dalam Meminimalisasi Perilaku Plagiasi Mahasiswa
}

\author{
Risa Rosalia ${ }^{1}$, A. Jauhar Fuad ${ }^{2}$ \\ ${ }^{1}$ Institut Agama Islam Tribakti Kediri, ${ }^{2}$ Institut Agama Islam Tribakti Kediri \\ ${ }^{1}$ risa.rosalia2019@gmail.com, ${ }^{2}$ info.ajauharfuad@gmail.com
}

\begin{abstract}
This study aims to determine the role of lecturers in minimizing plagiarism behavior of students. This study uses a qualitative method with interview and documentation data collection techniques. The results of the study found that : (1) socialization to students related to plagiarism, providing understanding of writing scientific papers and understanding of plagiarism, (2) students are required to revise their writing indicated plagiarism, (3) students who do plagiarism do not get assignments, (4) improve students reading culture; (5) teaches students about sentences paraphrasing, encourages indirect qoutations, provides journal references for students; (6) requires students to actively participate in discussion forums; (7) calls for retention from print books; (8) requires students to take online classes; (9) check plagiarism online; (10) giving assignments by hand; (11) determine the limit of plagiarism tolerance in accordance with the guidelines for writing scientific papers.
\end{abstract}

\section{Keywords: The Role of Lecturers, Plagiarism Behavior, Students}

\begin{abstract}
Abstrak
Penelitian ini bertujuan untuk mengetahui peran dosen dalam meminimalisasi perilaku plagiasi mahasiswa. Penelitian ini menggunakan metode kuliatatif dengan teknik pengumpulan data wawancara dan dokumentasi. Hasil penelitian menemukan bahwa; (1) sosialisasi kepada mahasiswa terkait plagiasi, memberikan pemahaman mengenai penulisan karya ilmiah dan pemahaman mengenai plagiasi; (2) mahasiswa diharuskan merevisi tulisannya yang terindikasi plagiasi; (3) mahasiswa yang melakukan plagiasi tidak mendapatkan nilai tugas; (4) meningkatkan budaya baca mahasiswa; (5) mengajarkan kepada mahasiswa tentang parafhrase kalimat, menghimbau agar melakukan kutipan tidak langsung, memberi referensi jurnal untuk mahasiswa; (6) mengharuskan mahasiswa untuk aktif mengikuti forum diskusi; (7) menghimbau pengambilan reverensi dari buku cetak; (8) mewajibkan mahasiswa mengikuti kelas online; (9) melakukan cek plagiasi online; (10) memberikan tugas dengan tulis tangan; (11) menetapkan batas toleransi plagiasi sesuai buku pedoman penulisan karya ilmiah.
\end{abstract}

Kata Kunci: Peran Dosen, Perilaku Plagiasi. Mahasiswa

\section{Pendahuluan}

Istilah kecurangan akademik sudah banyak dibicarakan oleh para ahli, Bower mendefinisikan cheating adalah perbuatan atau perilaku menggunakan cara yang tidak 
baik demi mencapai tujuan yang sah yaitu mendapatkan keberhasilan akademik demi menghindari kegagalan akademik. ${ }^{1}$ Salah satu kasus kecurangan dalam dunia akademik terkhusus dalam dunia perkuliahan adalah fenomena plagiasi karya ilmiah.

Tindakan yang tidak terpuji ini, tidak keseluruhan mahasiswa melakukan kecurangan akademik dengan sadar dan sengaja. Terdapat beberapa mahasiswa yang tidak menyadari bahwa yang mereka lakukan adalah sebuah tindakan kecurangan yang dapat dikenai sanksi, adanya keinginan untuk memperoleh IPK yang tinggi, prestasi dibidang akademik, kebanggaan atau karena harga diri terkadang membuat mahasiswa melakukan tindakan kecurangan akademik. ${ }^{2}$

Fenomena plagiasi merupakan suatu fenomena yang marak terjadi didalam masyarakat, terutama di dunia akademik. ${ }^{3}$ Dalam Permendiknas No.17 Tahun 2010 tentang pencegahan dan penanggulangan plagiat diperguruan tinggi menyebutkan Plagiat sebagai perbuatan sengaja atau tidak sengaja dalam memperoleh nilai untuk suatu karya ilmiah, dengan mengutip sebagian atau seluruh karya pihak lain dan diakui sebagai karya ilmiahnya, tanpa menyatakan sumber rujukan secara tepat dan memadai. ${ }^{4}$

Dalam dunia akademis mahasiswa dituntut memiliki kompetensi menulis karya ilmiah yang memiliki nilai tinggi. Salah satu nilai penulisan tertinggi adalah orisinalitas atau keaslian. Yang dimaksud adalah bahwa dalam sebuah karya ilmiah harus memiliki nilai kualitas dalam keaslian, objektivitas dan kejujuran, makna "asli" tidak semua ide, ide dan pengetahuan yang disampaikan seseorang dalam tulisannya berasal dari dirinya sendiri, melainkan kejujuran dalam mengekspresikan karyanya. menulis, yaitu jika katakata, kalimat, paragraf, ide, ide atau pendapat yang muncul dalam tulisan mereka milik orang lain (atau dari sumber lain), etika ilmiah adalah memasukkan sumber dengan jujur dan obyektif di mana ia mendapatkan kutipan. ${ }^{5}$

Namun permasalahan yang urgen terjadi pada mahasiswa di Indonesia adalah tingginya angka kasus plagiasi karya ilmiah baik berbentuk makalah, artikel sampai skripsi. Seperti yang dikatakan Davis Fishbein dan Bowers yang dikutip oleh Dhanis mengungkapkan bahwa tingginya angka plagiasi dalam lingkup akademik saat ini merupakan suatu bukti bahwa kaum intelektual (dosen, mahasiswa, guru professional) tidak lagi menjunjung tinggi asas-asas kejujuran dan etika dalam menghasilkan karya ilmiah. ${ }^{6}$

\footnotetext{
${ }^{1}$ Desi Purnamasari, "Faktor-Faktor yang Mempengaruhi Kecurangan Akademik pada Mahasiswa", Educational Psychology Journal, Vol. 2, 1 (2013), h. 14.

${ }^{2}$ Endra Murti Sagoro, "Pensinergian Mahasiswa, Dosen dan Lembaga dalam Pencegahan Kecurangan Akademik Mahasiswa Akuntansi”, Jurnal Pendidikan Akuntansi Indonesia, Vol. XI, 2 (2013), h. 55 .

${ }^{3}$ Riska Fajar Arista dan Refri Handini Listyana, "Plagiarisme Dikalangan Mahasiswa", Paradigma, Vol.3, 1 (2015), h. 1.

${ }^{4}$ Hari Santoso, "Pencegahan dan Penanggulangan Plagiarisme dalam Penulisan Karya Ilmiah dilingkungan Perpustakaan Perguruan Tinggi”, (28 Juli 2015), h. 3.

${ }^{5}$ Mulyana, "Pencegahan Tindak Plagiarisme dalam Penulisan Skripsi", cakrawala pendidikan, no. 3 (mei, 2010), h. 59.

${ }^{6}$ Dhanis Hidrawati. dkk, "Habituasi Plagiasrisme Tugas Kuliah dikalangan Mahasiswa FKIP UNS", Jurnal Ilmiah Pendidikan Sosiologi-Antropologi, Vol.5, 2 (2015), h. 5.
} 
Jujur adalah perilaku seseorang baik kepada dirinya sendiri maupun terhadap orang lain yaitu dapat dipercaya baik dalam perkataan, tindakan, pekerjaannya. ${ }^{7}$ Sudah seharusnya mahasiswa sebagai kaum intelektual dengan pendidikan yang tinggi mampu memiliki sifat jujur dalam setiap aktivitasnya baik didalam maupun diluar kampus.

Padahal dalam tugas Tri Dharma perguruan tinggi salah satunya adalah kewajiban membuat karya tulis. Seiring dengan tugasnya dalam proses pembelajaran, mahasiswa tidak pernah lepas dari tugas membuat makalah ataupun tugas akhir, fenomena dilapangan sering ditemukan perilaku yang tidak baik, yaitu guna memenuhi tugas dosen dengan waktu terbatas dan faktor nilai, mahasiswa sering melakukan plagiasi terhadap karya tulis orang lain melalui media buku ataupun media internet. ${ }^{8}$ Salah satunya yaitu tindakan mahasiswa menyelesaikan tugas akademik dengan cara instan Copas (copy paste) pada penyelesaian tugas akademik yaitu paper, makalah, review, artikel, skripsi dan karya ilmiah lainnya. ${ }^{9}$ Yaitu mahasiswa meneliti masalah yang sama persis yang dilakukan orang lain. ${ }^{10}$

Adapun beberapa faktor yang sering menjadi penyebab terjadinya perilaku plagiarisme yaitu kurang memiliki pengetahuan tentang penulisan karya ilmiah serta masalah plagiarisme, malas, ingin mencari jalan pintas dalam mencapai prestasi, terdesak waktu. ${ }^{11}$ Serta kurangnya kepercayaan diri pada mahasiswa bahwa mereka mampu menyelesaikan tugas dengan baik.

Hampir diseluruh perguruan tinggi di Indonesia masih terdapat kasus plagiasi yang mana hal tersebut masih sangat sulit untuk diatasi dan diperbaiki, tidak terkecuali di Institut Agama Islam Tribakti Lirboyo Kediri yang masih terdapat beberapa tindakan plagiasi yang dilakukan oleh para mahasiswa dalam mengerjakan tugas kuliah baik disengaja maupun tidak dan dengan berbagai faktor yang melatarbelakanginya. Padahal di dalam buku pedoman penulisan karya tulis ilmiah makalah, proposal, dan skripsi telah dicantumkan dan dijelaskan peraturan tentang tidakan plagiasi serta konsekuensinya dalam konteks akademika. Yaitu salinan Permendiknas No. 17 Tahun 2010. ${ }^{12}$

Maka dari itu peran dosen sangatlah penting dalam hal perbaikan kecurangan akademik, demi kemajuan pendidikan, dan demi mencetak generasi bangsa yang unggul, berkualitas, jujur, berkarakter, dan berprestasi. Berdasarkan konteks permasalahan tersebut, peneliti tertarik untuk mengkaji lebih dalam tentang sikap dosen dan usaha yang dilakukan dosen dalam meminimalisir tindakan plagiasi di Institut Agama Islam Tribakti Lirboyo Kediri.

${ }^{7}$ I Made Arsa Wiguna, "Metode Resitasi Berbasis TIK sebagai Upaya Penguatan Karakter Mahasiswa", Cetta : Jurnal Ilmu Pendidikan, Vol. 1, 2 (1 juni, 2018), h. 103.

${ }^{8}$ Khoirul Hidayah, "Tingkat Pemahaman Mahasiswa tentang Perlindungan Hak Cipta atas Karya Tulis", Jurnal Syari'ah Dan Hukum, Vol. 5, 1 (Juni, 2013), h. 53.

${ }^{9}$ Imroatullayyin Makhfiyana dan Moh. Mudzakkir, "Rasionalitas Plagiarisme dikalangan Mahasiswa Fakultas Ilmu Sosial Unesa", Paradigma, Vol. 1, 3 (2013), h. 4.

${ }^{10}$ Juliansyah Noor, Metodologi Penelitian Skripsi, Tesis, Disertasi \& Karya Ilmiah (Jakarta : Kencana, 2017), h. 27.

${ }^{11}$ Soetanto Hendrawan, Memahami Plagiarisme Akademik, 2014, h. 21.

${ }^{12}$ Zaenal Arifin dan Edi Nurhidin (eds), Pedoman Penulisan Karya Tulis Ilmiah Makalah, Proposal, Dan Skripsi (Kediri : IAIT Press, 2018), h. 108. 


\section{Metode Penelitian}

Penelitian ini dilakukan di Institut Agama Islam Tribakti Kediri yang terletak di J1. KH. Wahid Hasyim No. 62 Kediri. Penelitian ini adalah untuk mengetahui peran dosen dalam meminimalisasi perilaku plagiasi mahasiswa fakultas tabiyah IAI Tribakti Lirboyo Kediri. Sebagai upaya untuk memperoleh kebenaran atau jawaban dari berbagai pertanyaan, maka dengan ini penulis menggunakan pendekatan kualitatif, Menurut Bogdan dan Tailor sebagaimana dikutip Moleong mendefinisikan nmetodologi kualitatif sebagai prosedur penelitian yang menghasilkan data deskriptif berupa kata-kata tertulis atau lisan dari orang-orang dan perilaku yang dapat diamati. ${ }^{13}$ Sedangkan pendekatan yang peneliti gunakan adalah pendekatan studi kasus sebagai langkah untuk memahami objek yang diteliti sebagai studi kasus. Oleh karena itu peneliti mengunakan wawancara mendalam dan sebagai langkah pengumpulan data. Informan sendiri terdiri dari 8 dosen dan 9 mahasiswa fakultas tarbiyah yang terdiri dari prodi PAI dan PGMI.

\section{Pembahasan}

\section{Perilaku Plagiasi di Kalangan Akademis dan Bentuk-bentuknya}

Perilaku plagiasi merupakan salah satu bentuk ketidakjujuran dan ketidakdisiplinan dalam konteks akademik yang melanggar etika (akhlak). Pelanggaran tersebut berdampak negatif bagi para pelaku plagiat. Menurut peraturan Menteri Pendidikan Nasional Nomor 17 Tahun 2010 :

Plagiat adalah perbuatan sengaja atau tidak sengaja dalam memperoleh atau mencoba memperoleh kredit atau nilai untuk suatu karya ilmiah, dengan mengutip sebagian atau seluruh karya dan atau karya ilmiah pihak lain yang diakui sebagai karya ilmiahnya, tanpa menyatakan sumber secara tepat dan memadai. ${ }^{14}$

Plagiasi sendiri merupakan fenomena universal yang masih terjadi dalam dunia pendidikan salah satunya di perguruan tinggi, sejak abad ke-19 plagiasi telah menjadi masalah yang serius dalam dunia pendidikan dan masih berlangsung hingga saat ini. ${ }^{15}$ Tidak jarang ditemukan beberapa kasus yang masih sering terjadi yaitu tindakan plagiasi yang dilakukan demi mendapatkan keuntungan pribadi, salah satu contoh yaitu kasus pelepasan gelar doktor, hal ini mengindikasikan bahwasanya plagiasi masih marak terjadi dilingkungan akademik.

Dewasa ini, Plagiarisme tumbuh subur di Indonesia, baik di kalangan perguruan tinggi (akademik) maupun di kalangan publikasi ilmiah adalah disebabkan oleh beberapa faktor yakni karena : (1) kurangnya pelatihan atau sosialisasi yang mengakibatkan orang tidak tahu tentang tata cara menulis yang baik dan taat asas,; (2) kurangnya akses kepada

\footnotetext{
${ }^{13}$ Lexy J. Moleong, MetodologiPenelitianKualitatif (Bandung: PT. Remaja Rosdakarya, 2017), h. 4. ${ }^{14}$ Zaenal Arifin dan Edi Nurhidin (eds), h. 30.

${ }^{15}$ Lulu Andarini Aziz. dkk, "Upaya Perpustakaan dalam Mengurangi Plagiarisme Pada Karya Ilmiah Mahasiswa (Studi Kasus di UPT Perpustakaan UNIKA Soegijapranata”, Jurnal Ilmu Perpustakaan, Vol. 4, 3 (juli 2015), h. 2.
} 
sumber kepustakaan; (3) rendahnya apresiasi atau rasa hormat kepada sesama penulis; dan (4) rendahnya atau tidak adanya sanksi bagi seorang plagiat. ${ }^{16}$

Tidak terkecuali di IAIT Kediri yang masih ditemukan beberapa tindakan plagiasi yang dilakukan oleh mahasiswa dalam penulisan karya ilmiah baik makalah, artikel maupun skripsi. hal ini terjadi karena beberapa faktor yang mengakibatkan mahasiswa melakukan plagiasi, diantaranya Karena di IAIT sendiri mahasiswa yang melakukan tindakan plagisi masih kurang terdeteksi, minimnya pemahaman keilmuan mahasiswa, budaya baca mahasiswa yang masih sangat kurang, terdapat beberapa dosen dan mahasiswa yang masih kurang memahami hal-hal yang berkaitan dengan perilaku plagiasi karya ilmiah serta letak geografis kampus yang berada dipinggiran kota (tidak berada dikota besar) sehingga akses pertukaran informasi yang diterimapun tidak secepat dan semudah kampus yang berada dikota-kota besar lainnya.

Mayoritas mahasiswa IAIT mengartikan plagiasi adalah suatu kecurangan akademik yaitu meniru, menjiplak atau menyalin karya orang lain baik dari buku maupun internet tanpa mencantumkan sumber reverensi yang jelas dan lengkap. Plagiasi memiliki definisi yang beragam, namun pada intinya yaitu menggunakan atau mengambil karya orang lain seolah karyanya sendiri. ${ }^{17}$ tulisan hasil plagiasi tidak akan memajukan ilmu pengetahuan karena dengan melakukan plagiasi penulis hanya akan melakukan pengulangan ide dan mendaur ulang tulisan milik orang lain atau bahkan miliknya sendiri serta akan mematikan kreatifitas dan pola pikir dalam penulisan karya ilmiah. Karya tulis ilmiah adalah karangan ilmu pengetahuan yang didalamnya menyajikan kebenaran dan fakta yang disertai dengan bukti-bukti yang empiris. ${ }^{18}$ namun hal yang sering terjadi dalam penulisan karya ilmiah yaitu ketika penulis hendak mengambil rujukan atau reverensi dari penulis lain, disinilah sering terjadi tindakan plagiasi baik disengaja maupun tidak disengaja.

Berbagai bentuk plagiasi sering terjadi. dalam peraturan Mendiknas No. 17 Tahun 2010, terdapat lima bentuk plagiarisme yang sering terjadi dan dilakukan secara sengaja di lingkungan akademik atau perguruan tinggi, yaitu sebagai berikut :

a. Mengacu dan/mengutip istilah, kata-kata dan/kalimat, data dan/informasi dari suatu sumber tanpa menyebutkan sumber dalam catatan kutipan dan/atau tanpa menyatakan sumber secara memadai

b. Mengacu dan/mengutip secara acak istilah, kata-kata dan/kalimat, data dan/informasi dari suatu sumber tanpa menyebutkan sumber dalam catatan kutipan dan/atau tanpa menyatakan sumber secara memadai

c. Menggunakan sumber gagasan, pendapat, pandangan, atau teori tanpa menyatakan sumber secara memadai

d. Merumuskan dengan kata-kata dan/atau kalimatsendiri dari sumber kata-kata dan/atau kalimat, gagasan, pendapat, pandangan, atau teori tanpa menyatakan sumber secara memadai

16

${ }^{17}$ Etty Indriati, Strategi Hindari Plagiarisme (Jakarta : PT gramedia pustaka utama, 2015), h. 2.

${ }^{18}$ Indriati, h. 70.

Indonesian Journal of Islamic Education Studies (IJIES)

Volume 2, Nomor 1, Juni 2019 
e. Menyerahkan suatu karya ilmiah yang dihasilkan dan/atau telah dipublikasikan oleh pihak lain sebagai karya ilmiahnya tanpa menyatakan sumber secara memadai. ${ }^{19}$

Sedangkan Dhanis Hidrawati dkk, dalam penelitiannya tentang habituasi plagiarisme tugas kuliah mahasiswa, membagi jenis-jenis plagiasi menjadi 4 macam, yaitu :

a. Plagiarisme total yaitu : tindakan plagiat yang dilakukan oleh seorang penulis dengan cara menjiplak atau mencuri hasil karya orang lain seluruhnya dan mengklain sebagai karyanya sendiri.

b. Plagiarisme parsial yaitu : tindakan plagiat yang dilakukan oleh seorang penulis dengan cara menjiplak sebagian hasil karya orang lain untuk dijadikan hasil karyanya sendiri.

c. Auto plagiasi (self plagiarisme) yaitu : plagiasi yang dilakukan seorang penulis terhadap karyanya sendiri, baik secara menyeluruh atau sebagian.

d. Plagiarisme antar bahasa yaitu : tindakan plagiat yang dilakukan oleh seorang penulis dengan cara menerjemahkan suatu karya tulis yang berbahasa asing kedalam bahasa Indonesia. ${ }^{20}$

Tidak hanya itu saja, plagiat mempunyai ruang lingkup yang luas. tidak hanya sekedar plagiat dalam definisi saja, tetapi juga dalam bentuk, jenis dan macamnya. Selanjutnya penting untuk mengetahui tipe-tipe plagiat yang disarikan dari tulisan Parvaty Iyer dan Abhibsita Singh yang dikutip oleh Sulistyo sebagai berikut :

a. Plagiat berdasarkan aspek yang dicuri

1) Plagiarisme ide (plagiarism of idea)

Tipe plagiarisme ini relatif sulit dibuktikan karena ide atau gagasan itu bersifat abstrak dan berkemungkinan memiliki persamaan dengan ide rang lain. Atau, ada kemungkinan terjadi adanya dua ide yang sama pada dua orang pencipta yang berbeda. Misalnya, ide tentang cerita sinetron percintaan dengan latar belakang kehidupan mahasiswa dikampus UPH. Ide seperti ini sangat umum dan sangat mungkin mempunyai kesamaan dengan ide orang lain. Oleh karena itu, perlu bahan bukti yang cukup untuk memastikan adanya plagiarisme.

2) Plagiarisme kata demi kata (word for word plagiarism)

Tipe ini serupa dengan slavish copy, yaitu mengutip karya orang lain secara kata demi kata tanpa menyebutkan sumbernya. Plagiarisme dianggap terjadi karena skala pengutipannya sangat substansial sehingga seluruh idea tau gagasan penulisnya benar-benar terambil. Plagiarisme seperti ini banyak dilakukan pada karya tulis puisi.

3) Plagiarisme atas sumber (plagiarism of source)

Plagiarisme tipe ini memiliki 'dosa' karena tidak menyebutkan secara lengkap selengkap-selengkapnya referensi yang dirujuk dalam kutipan. Jika sumber kutipan itu merujuk seseorang sebagai penulis yang terkait dengan kutipan, maka nama penulis tersebut harus ikut serta disebut. Ini tentu sikap fair

${ }^{19}$ Zaenal Arifin dan Edi Nurhidin (eds), h. 111.

${ }^{20}$ Hidrawati, "Habituasi plagiarisme tugas, h. 4-5.

Indonesian Journal of Islamic Education Studies (IJIES)

Volume 2, Nomor 1, Juni 2019 
dan tidak merugikan kapentingan penulis tersebut serta kontributor-kontributor lainnya.

4) Plagiarisme kepengarangan (plagiarism of authorship)

Plagiarisme kepengarangan terjadi apabila seseorang mengaku sebagai pengarang dari karya tulis yang disusun oleh orang lain. Tindakan ini terjadi atas kesadaran dan motif kesengajaan untuk "membohongi" publik. Misalnya, mengganti cover (sampul) buku atau karya tulis orang lain dengan sampul atas namanya tanpa ijin. kasus seperti ini pernah terjadi di Cirebon yang melibatkan dosen salah satu perguruan tinggi di kota itu.

b. Klasifikasi berdasarkan sengaja atau tidaknya plagiarisme

Bila seseorang menggunakan ide, kata, frase, kalimat, atau paragraf orang lain tanpa menyebut sumber, mungkin hal tersebut memang disengaja oleh penulis, namun mungkin juga karena "tidak sengaja", misalnya ia tidak mengetahui bahwa hal tersebut tidak boleh dilakukan. Namun kedua hal tersebut harus diberi penilaian yang sama, harus mendapat sanksi yang sama. "Saya tidak bermaksud begitu kok", bukan ungkapan yang dapat menghilangkan tuduhan bahwa ia melakukan plagiarisme. Plagiarisme bersifat universal. Tidak ada atau belum adanya peraturan di suatu lembaga pendidikan tentang plagiarisme tidak membuat orang boleh melakukan plagiarisme. Plagiarisme adalah pencurian; tidak boleh orang mencuri dengan alasan "saya tidak tahu ada undang-undang atau peraturan yang melarang pencurian".

c. Klasifikasi berdasarkan proporsi atau persentasi kata, kalimat, paragraf yang dibajak

1) Plagiarisme ringan manakala dalam penulisan karya tulis ilmiah yang dibuat oleh seseorang kurang dari : $<30 \%$.

2) Plagiarisme sedang : plagiat yang mempunyai prosentasi $30-70 \%$.

3) Plagiarisme berat atau total : plagiat yang lebih dari : $<70 \%$ isi karya tulis ilmiahnya merupakan plagiat dari karya orang lain. Plagiat ini tidak bisa ditoleransi dan karya tersebut harus direvisi ataupun tidak diakui. ${ }^{21}$

Berbagai bentuk plagiasi diatas hendaknya mahasiswa dapat memahami masalah tentang plagiarism. Karena hal tersebut dianggap berbahaya dan merugikan bagi perkembangan ilmu pengetahuan karena seharusnya ilmu pengetahuan dihasilkan melalui suatu proses yang benar dan jujur. Namun keilmuan sekarang justru dihasilkan dengan cara yang tidak beretika. Orang-orang berpendidikan yang harusnya tahu tentang etika kejujuran, justru bertimpang balik dengan posisinya sebagai seorang pelajar. Tak pelak mereka hanya mencari jalan pintas untuk mendapatkan ijazah atau jabatan melalui plagiasi karya ilmiah.

Padahal ilmu pengetahuan manusia tidak diperoleh semuanya dengan seketika melainkan melalui berbagai tahapan penelitian yang dilakukan oleh banyak orang dari generasi ke generasi. Oleh karena itu, sangatlah penting bagi ilmuwan untuk saling menghargai jerih payah orang lain. Melakukan plagiarisme berarti tidak menghargai jerih

21 Sudigdo Sastroasmoro, "Beberapa catatan tentang Plagiarisme", Mahasiswa Kedokteran Indonesia, Vol. 57, (8 Agustus 2007), h. 240-242.

Indonesian Journal of Islamic Education Studies (IJIES)

Volume 2, Nomor 1, Juni 2019 
payah sesama peneliti atau penulis yang ilmunya sudah menjadi bagian dari kekayaan ilmu pengetahuan. Oleh karena itu, selayaknya, pendidikan kita menempatkan subyek pemahaman tentang plagiarisme sebagai hal penting yang harus difahami agar plagiarisme dapat dicegah.

\section{Fenomena Perilaku Plagiasi Mahasiswa Fakultas Tarbiyah IAIT Kediri}

Plagiasi merupakan fenomena universal yang masih terjadi dalam dunia pendidikan salah satunya diperguruan tinggi, sejak abad ke-19 plagiasi telah menjadi masalah yang serius dalam dunia pendidikan dan masih berlangsung hingga saat ini. ${ }^{22}$ Tidak jarang ditemukan beberapa kasus yang masih sering terjadi yaitu tindakan plagiasi yang dilakukan demi mendapatkan keuntungan pribadi, salah satu contoh yaitu kasus pelepasan gelar doktor, hal ini mengindikasikan bahwasanya plagiasi masih marak terjadi dilingkungan akademik.

Plagiasi dalam konteks penulisan karya ilmiah memang menjadi sorotan dan masih menjadi problem sering terjadi di perguruan tinggi tidak terkecuali di IAIT Kediri yang masih ditemukan beberapa tindakan plagiasi yang dilakukan oleh mahasiswa dalam penulisan karya ilmiah baik makalah, artikel maupun skripsi. Secara umum fenomena plagiasi dikalangan mahasiswa memiliki banyak faktor di antaranya

1. Dosen dan mahasiswa sama-sama tidak mengerti apa itu plagaisi dan apa saja yang termasuk dalam kriteria plagiasi. dari mahasiswa sendiri merasa dimudahkan dengan perkembangan teknologi untuk mengakses informasi secara online.

2. Isu plagiasi yang tidak disosialisasikan secara menyeluruh dikalangan dosen. hal ini terjadi karena Tribakti termasuk kampus yang berada dipinggiran kota yang mana akses pengetahuan dan informasi tidak secepat dengan perguruan tinggi yang berada dikota-kota besar. lingkungan akademik tidak menafikan menjadi faktor munculnya tindakan plagiasi. Karena antara perguruan swasta dengan perguruan negeri ada beberapa perbedaan. Pertukaran informasi di perguruan negeri lebih baik dan cepat dibanding dengan perguruan swasta. Oleh hal ini kembali kepada kemampuan dosen atau pimpinan dalam mengakses kebijakan pemerintah tentang plagiasi. $^{23}$

Mayoritas mahasiswa IAIT mengartikan plagiasi adalah suatu kecurangan akademik yaitu meniru, menjiplak atau menyalin karya orang lain baik dari buku maupun internet tanpa mencantumkan sumber reverensi yang jelas dan lengkap. Plagiasi memiliki definisi yang beragam, namun pada intinya yaitu menggunakan atau mengambil karya orang lain seolah karyanya sendiri. ${ }^{24}$ tulisan hasil plagiasi tidak akan memajukan ilmu pengetahuan karena dengan melakukan plagiasi penulis hanya akan melakukan pengulangan ide dan mendaur ulang tulisan milik orang lain atau bahkan miliknya sendiri serta akan mematikan kreatifitas dan pola pikir dalam penulisan karya ilmiah. Karya tulis

\footnotetext{
${ }^{22}$ Lulu Andarini Aziz. dkk, "Upaya Perpustakaan dalam Mengurangi Plagiarisme Pada Karya Ilmiah Mahasiswa (Studi Kasus di UPT Perpustakaan UNIKA Soegijapranata”, Jurnal Ilmu Perpustakaan, Vol. 4, 3 (juli 2015), h. 2.

${ }^{23}$ Edi Nurhidin, Wawancara, Kantor P3M IAIT Kediri, 12 Februari 2019.

${ }^{24}$ Etty Indriati, Strategi Hindari Plagiarisme (Jakarta : PT gramedia pustaka utama, 2015), h. 2.
} 
ilmiah adalah karangan ilmu pengetahuan yang didalamnya menyajikan kebenaran dan fakta yang disertai dengan bukti-bukti yang empiris. ${ }^{25}$ namun hal yang sering terjadi dalam penulisan karya ilmiah yaitu ketika penulis hendak mengambil rujukan atau reverensi dari penulis lain, disinilah sering terjadi tindakan plagiasi baik disengaja maupun tidak disengaja.

Ada mahasiswa yang telah memahami dan mengetahui bahwa perilaku plagiasi adalah hal yang merugikan dan telah ada peraturan yang melarangnya, namun mayoritas mahasiswa masih tetap melakukannya serta menganggap tindakan tersebut merupakan hal yang wajar dan biasa untuk dilakukan. Namun ada mahasiswa yang telah menerapkan perilaku anti plagiasi dengan sebisa mungkin meminimalisasi plagiasi dalam penulisan karya ilmiah, hal ini terjadi lantaran berbagai nasehat dan motivasi yang diberikan oleh dosen yang mampu memberikan dorongan kepada mahasiswa untuk memiliki kepercayaan diri dalam kemampuan menulisnya.

Plagiasi sendiri menurut sudut pandang salah satu Dosen di IAI Tribakti ketika diminta menanggapi fenomena di kalangan akademis, menganggap bahwasanya plagiasi merupakan tindakan mengambil atau mencuri karya orang lain dan menganggap hal tersebut merupakan karya penulis sendiri tanpa memberi referensi yang jelas. Tindakan ini merupakan salah satu bentuk kecurangan akademik yang masih marak terjadi dilingkup akademisi yang akhirnya dapat mematikan pola pikir mahasiswa. ${ }^{26}$

Pendapat di atas didukung dengan pendapat Zaenal Arifin selaku ketua P3M di IAI Tribakti menurutnya, "Setiap perguruan tinggi memiliki orientasi yang berbeda, namun mengenai perilaku plagiasi tetap menjadi masalah yang terjadi disetiap perguruan tinggi. Bahkan belum lama ini terdapat kasus pelepasan gelar doktor hal ini mengindikasikan bahwasanya plagiasi masih marak terjadi di lingkungan akademik.",27

Meninjau dari pemaparan beberapa dosen terkait perilaku plagiasi mahasiswa yang secara umum masih terjadi diberbagai perguruan tinggi, maka tak terkecuali dengan IAI Tribakti yang sampai saat ini masih saja ditemukan mahasiswa yang melakukan tindakan plagiasi dalam penulisan karya ilmiah. Namun problem yang terjadi di kampus IAI tindakan plagiasi yang dilakukan oleh mahasiswa masih kurang terdeteksi karena berbagai faktor. Oleh karena itu dosen memiliki peran ganda yakni sebagai sumber tranfer ilmu dan mentor mahasiswa dalam penulisan karya ilmiah. dalam artian di samping sebagai sumber ilmu, dosen juga berperan untuk memperingatkan dan membangun kesadaran mahasiswa untuk menghindari plagiasi. Jika mahasiswa belum mengerti, maka tugas dosenlah yang harus memberi pemahaman kepada mahsiswa.

\section{Latar Belakang Mahasiswa Melakukan Perilaku Plagiasi}

Plagiasi terjadi karena melemahnya integritas mahasiswa. Integritas akademik adalah perilaku jujur yang harus diterapkan dalam semua hal yang berhubungan dengan lingkungan akademik. ${ }^{28}$ banyak hal yang menyebabkan lahirnya ketidakjujuran akademik (plagiasi) diantaranya yaitu keinginan untuk mendapat nilai bagus, pengaruh

\footnotetext{
${ }^{25}$ Indriati, h. 70.

${ }^{26}$ M. Mukhlison, Wawancara, Kantor P3M IAIT Kediri, 28 Februari 2019.

${ }^{27}$ Zaenal Arifin, Wanwancara, kantor P3M IAIT Kediri, 27 Februari 2019.

${ }^{28}$ Agus Ardiansyah. dkk, "ketidakjujuran akademik dalam pendidikan tinggi", (01 Juli 2018), h. 6.
} 
lingkungan dan lain-lain. Dengan berbagai hal tersebut akhirnya muncullah faktor-faktor yang melatar belakangi mahasiswa melakukan perilaku plagiasi yaitu

Pertama, mahasiswa belum terlalu memahami perihal mengenai perilaku plagiasi. Mayoritas mahasiswa yang melakukan tindakan plagiasi lantaran belum mengetahui pengertian plagiasi serta hal-hal yang berkaitan dengan plagiasi. memang diawal perkuliahan dosen selalu memberikan pemahaman mengenai tindakan plagiasi namun tidak secara keseluruhan. Minimya sosialisasi terkait plagiasi yang akhirmya memberi dampak ketidaktahuan mahasiswa mengenai hal-hal yang berkaitan dengan plagiasi serta konsep dan sistematika mengerjakan karya ilmiah dengan baik dan benar. ${ }^{29}$

Kedua yaitu sifat malas dan kurang percaya dengan kemampuan diri sendiri. Banyak mahasiswa yang malas dalam mencari sumber pengetahuan serta sumber referensi serta tidak memiliki keyakinan bahwa dirinya mampu menulis karya ilmiah. Hal tersebut sesuai dengan pendapat Aini yang dikutip oleh Aditya, salah satu faktor plagiasi adalah malas. Malas adalah penyakit yang menular khususnya istilah ini layak digunakan untuk memotret fenomena yang terjadi di Indonesia. Pemuda usia produktif yang mayoritas masih berstatus pelajar seakan mempunyai penyakit malas ini, dari malas muncullah banyak permasalahan salah satunya tindakan plagiasi. Contoh ketika mahasiswa malas mencari informasi terkait tata cara penulisan karya ilmiah yang baik dan benar, cara pengutipan yang benar, maka akan lebih mudah terjerumus melakukan tindakan plagiasi. $^{30}$

Ketiga, kurangnya budaya baca mahasiswa yang membuat mahasiswa merasa kesulitan dalam menemukan referensi untuk tugasnya. Menurut data kemendikbud yang dikutip oleh Lulu Andarini, plagiat dapat terjadi karena minimnya ketersediaan sumber bacaan di perpustakaan. ${ }^{31}$ Dari minimnya ketersediaan buku tersebut menambah berkurangnya minat baca mahasiswa yang akhirnya mendorong mahasiswa melakukan plagiasi.

Keempat, keterbatasan waktu. Hal ini juga dialami oleh mahasiswa yang berdomisili di Pondok Pesantren yang sering terbentur dengan kegiatan pondok yang sangat padat. Hal tersebut seperti yang dikatan oleh Agus Wahyudi yang dikutip oleh Soelistyo seseorang sering melakukan plagiasi lantaran terdesak waktu. Seseorang harus melakukan kanibal dalam penyusunan karya ilmiah baik untuk melengkapi tugas akademik, dalam meraih gelar sarjana maupun mendapat predikat kelulusan lainnya. Tingkat penguasaan substansi dan lemahnya kemampuan dalam teknik menulis berpotensi mendorong seseorang melakukan tindakan plagiasi. ${ }^{32}$ Begitu pula dengan mahasiswa yang sibuk dalam organisasi kampus yang akhirnya memilih cara yang instan untuk menyelesaikan tugasnya, seperti yang diungkapkan oleh Imroatullayyin yaitu mahasiswa yang mengikuti organisasi khususnya Badan Eksekutif Mahasiswa (BEM) lebih memilih menyelesaikan tugas kuliahnya dengan cara yang instan yaitu dengan melakukan tindakan plagiasi, mahasiswa tidak memperdulikan kualitas tulisannya,

\footnotetext{
${ }^{29}$ Arista dan Listyana, Plagiarisme dikalangan Mahasiswa, h. 3.

${ }^{30}$ Aditya Pradiansyah, "Makna Plagiarisme bagi Mahasiswa Universitas Muhammadiyah", (Skripsi, Jurusan Psikologi Universitas Muhammadiyah Surakarta, Surakarta, 2015), h. 23.

${ }^{31}$ Aziz, Irhandayaningsih, Kurniawan, Upaya Perpustakaan dalam, h. 2.

${ }^{32}$ Henry Soelistyo, Plagiarisme : Pelanggaran Hak Cipta Etika (Yogyakarta : kanisius, 2011), h. 3. 
melainkan pada selesainya tugas dan bisa melanjutkan perannya dalam organisasi tersebut. $^{33}$

Kelima, mudah dan instan. Dalam dunia pendidikan terutama lingkup perkuliahan internet sangat bermanfaat untuk menunjang proses belajar mahasiswa. Namun disisi lain internet juga memiliki dampak negatif salah satunya munculnya tindakan plagiasi dalam dunia pendidikan. ${ }^{34}$ Adanya kecanggihan teknologi dapat memudahkan mahasiswa untuk mengakses internet. segala materi dan bahan untuk tugas akan sangat mudah ditemukan di internet. Bahkan dari hasil wawancara, mahasiswa cenderung melakuka copy paste dari internet dari pada buku. Hal ini dikarenakan jika melakukan plagiasi dari buku maka mahasiswa harus mengetik ulang materi yang ada dibuku dan jika dari internet mahasiswa hanya tinggal mengcopy paste tanpa harus mengetik ulang. Menurut Aini yang dikutip oleh Aditya menyebutkan salah satu faktor plagiasi adalah kecanggihan teknologi, perubahan zaman tidak bisa lepas dari bertambah canggih dan modernnya teknologi. Khususnya penggunaan teknologi dalam bidang pendidikan. Informasi dari karya seseorang dapat dengan mudah diakses siapa saja melalui internet, yang kemudian karya tersebut digunakan oleh pengakses untuk kepentingannya. ${ }^{35}$ Dari hasil survey mengenai plagiasi melalui internet yang dilakukan oleh Pew Research center, lembaga survey Amerika Serikat yang bekerja sama dengan laman The Chronicleof Higher Education terhadap 1055 mahasiswa, baik dari universitas negeri maupun swasta menyatakan bahwasanya sebanyak 55\% mahasiswa melakukan plagiat dalam 10 tahun terakhir, mayoritas mahasiswa yakni sebanyak $80 \%$ mengatakan computer dan internet memegang peran utama dalam hal tersebut. ${ }^{36}$

Keenam, berpikir bahwa dosen tidak akan tahu bahwa mahasiswa menjiplak atau copy paste tugas dari internet serta berpikir bahwa plagiasi merupakan hal yang wajar dilakukan dan sudah menjadi tradisi. Belum adanya peraturan yang ditetapkan mengenai kebijakan plagiasi untuk makalah membuat mahasiswa mudah untuk melakukan plagiasi serta kurangnya perhatian dari dosen seperti dosen kurang teliti dengan tugas yang dikerjakan oleh mahasiswa menyebabkan mahasiswa berpikir walaupun melakukan tindakan plagiasi dosen tidak akan mengetahui. Seperti pendapat Aini yang dikutip oleh Aditya yaitu salah satu faktor faktor plagiasi mahasiswa yaitu minimya pengawasan dari berbagai pihak, salah satunya dosen kurang memperhatikan karya tulis mahasiswa. ${ }^{37}$

Ketujuh, tuntutan tugas dari dosen. Tugas adalah salah satu bentuk komponen dari penilaian yang diberikan dosen kepada mahasiswa. ${ }^{38}$ Hal ini merupakan salah satu faktor yang sering menjadi penyebab mahasiswa melakukan tindakan plagiasi, seperti yang diungkapkan oleh I Made Arsa Wiguna yaitu pada fase pemberian tugas hendaknya dosen mempertimbangkan beberapa hal diantaranya : 1) memberikan tugas yang tepat dan jelas sehingga mahasiswa mengerti tentang tugas yang diberikan, 2) sesuai dengan

\footnotetext{
${ }^{33}$ Makhfiyana dan Mudzakkir, Rasionalitas Plagiarisme dikalangan, h. 5.

${ }^{34}$ Hidrawati, Budiati, Rohmad, Habituasi plagiasrisme tugas, h. 2.

${ }^{35}$ Pradiansyah, Makna Plagiarisme bagi, h. 28.

${ }^{36}$ Aziz, Irhandayaningsih, Kurniawan, Upaya Perpustakaan dalam, h. 2.

${ }^{37}$ Pradiansyah, Makna Plagiarisme bagi, h.28.

${ }^{38}$ Febrina Nafasati Prihantini dan Dian Indudewi, "Kesadaran dan Perilaku Plagiarisme dikalangan Mahasiswa (Studi pada Mahasiswa Fakultas Ekonomi Jurusan Akutansi Universitas Semarang)", Jurnal Dinamika Sosial Budaya, Vol.18, 1 (Juni 2016), h. 68.
} 
kemampuan mahasiswa, 3) memberi saran sumber reverensi 4) memberi waktu yang cukup untuk menyelasaikan tugas. ${ }^{39}$ Dengan minimnya buku yang ada diperpustakaan, akhirnya mahasiswa lebih memilih cara yang mudah yaitu internet sebagai sarana untuk mencari materi dan reverensi untuk tugasnya.

Kedelapan, untuk skripsi, banyak teori dan beberapa bahan yang memang harus diambil dari buku, internet dan jurnal. Hal ini menyebabkan mahasiswa terdeteksi melakukan plagiasi, karena banyak dari mahasiswa yang melakukan copy paste tanpa memparafrasekan kalimat yang diambil dari buku atau internet. Dari penjelasan di atas, terdapat berbagai macam faktor yang melatar belakangi terjadinya perilaku plagiasi dikalangan mahasiswa, maka dari itu amatlah penting peran seorang dosen dalam meminimalisasi hal tersebut.

\section{Sikap dan Tindakan Dosen Terhadap Perilaku Plagiasi Mahasiswa}

Adapun beberapa sikap atau tindakan dosen terkait tindakan plagiasi yang dilakukan oleh mahasiswa. Sosialisasi dosen kepada mahasiswa terkait dengan perilaku plagiasi. Bahwa setiap dosen selalu memberikan pemahaman kepada mahasiswa terkait dengan tindakan plagiasi, bahwa plagiasi adalah kejahatan akademik yang harus dihindari, namun hal tersebut tidak sampai menyentuh pada diri mahasiswa dibuktikan dengan masih banyak mahasiswa yang melakukan plagiasi dalam penulisan karya ilmiah.

Terkait sikap dosen terhadap plagiasi yang dilakukan oleh mahasiswa dalam penulisan karya ilmiah yaitu :

1) Memberikan nasehat dan teguran bahwa plagiasi merupakan tindakan tidak terpuji yang harus benar-benar dihindari serta menjelasakan konsekuensi yang akan diterima ketika mahasiswa terdeteksi melakukan plagiasi. Karena dalam kode etik karya ilmiah harus bersikap jujur. Sebagaimana yang dinyatakan oleh Armada Riyanto yang dikutip oleh Soelistyo menyatakan plagiarisme adalah pencurian kreativitas intelektual. Sementara itu maraknya tindakan plagiasi diakui sebagai dampak dari rusaknya bangunan nurani kejujuran. Untuk itu perlu ditetapkan sanksi hukum yang tepat dan terukur terkait tindak plagiarisme. Plagiarisme juga merupakan pengingkaran terhadap etika dan kultur akademik yang bermoral dan beretika, sehingga patut mendapatkan sanksi administratif yang setara. Selebihnya biarkan masyarakat dan civitas akademik menghukumnya dengan sanksi sosial, yakni kecaman dan cela setimpal dengan kesalahannya. ${ }^{40}$

2) Melakukan tindakan sesuai regulasi UUD. Ketika mahasiswa terbukti melakukan plagiasi menurut UUD yang berlaku yaitu boleh tidak meluluskan mahasiswa pada mata kuliah yang sedang ditempuh. Namun ada beberapa komponen lain yang dapat dipertimbangkan yaitu kehadiran mahasiswa, UTS, UAS, dan lain-lain.

3) Sebagai hukuman, mahasiswa diharuskan merevisi tulisannya, tetapi jika masih terdeteksi plagiasi, maka akan diberikan sanksi yang lebih berat yaitu pengurangan nilai. Sikap ini diberikan pada mahasiswa yang melakukan plagiasi untuk tingkatan plagiasi lebih dari 50\%. Hal ini sesuai dengan peraturan mendiknas No. 17 tahun

\footnotetext{
${ }^{39}$ Wiguna, Metode Resitasi Berbasis, h. 101.

${ }^{40}$ Soelistyo, Plagiarisme : Pelanggaran Hak, h. 47. 
2010. Hal ini dilakukan untuk memberikan efek jera terhadap mahasiswa agar mahasiswa dapat meminimalisasi tindakan plagiasi dalam penulisan karya ilmiah.

4) Pengumpulan artikel untuk cek plagiasi sesuai toleransi tingkat plagiasi yaitu $30 \%$.

\section{Usaha yang Dilakukan oleh Dosen dalam Meminimalisasi Perilaku Plagiasi Mahasiswa}

Dosen harus memiliki integritas yang baik dan tinggi. Karena ujung tombak pendidikan terletak pada seorang guru/dosen. Apabila karakter dosen tesebut tegas, disiplin, teliti dan kritis maka mahasiswa akan lebih berhati-hati dalam mengerjakan tugasnya. ${ }^{41}$ Maka, jika dosen memiliki integritas yang baik akan memberikan dampak yang positif bagi mahasiswanya serta dapat mengarahkan mahasiswa untuk menghindari dan meminimalisasi tindakan plagiasi dalam penulisan karya ilmiah terlepas dari berhasil tidaknya usaha yang dilakukan. maka disinilah peran penting yang harus dilaksanakan oleh setiap dosen.

Setiap dosen memiliki cara yang berbeda-beda dalam meminimalisasi perilaku plagiasi sesuai jenis penulisan karya ilmiah. Setidaknya ada 3 jenis penulisan karya ilmiah secara umum yang penulis dapat berdasarkan data yang diperoleh yakni penulisan makalah, artikel, dan skripsi.

Adapun beberapa usaha yang dilakukan oleh dosen dalam meminimalisasi perilaku plagiasi mahasiswa dalam penulisan makalah di antaranya:

1) Memberikan pemahaman mengenai penulisan karya ilmiah sesuai buku pedoman penulisan karya ilmiah dan pemahaman mengenai plagiasi dalam konteks intelektual yang memang harus dihindari oleh mahasiswa

2) Meningkatkan budaya baca mahasiswa untuk memperluas pengetahuannya. dengan cara dosen memberikan bahan referensi buku-buku yang dapat dibaca mahasiswa dalam menyelesaikan tugasnya. Seperti yang diungkapkan oleh I Made Arsa Wiguna, dengan upaya dosen memberikan beberapa sumber rujukan untuk bahan reverensi yang harus dibaca mahasiswa, maka minat baca mahasiswa akan meningkat. ${ }^{42}$ Dengan ini perilaku plagiasi mahasiswa akan semakin berkurang.

3) Mengharuskan mahasiswa untuk aktif mengikuti forum diskusi. Baik didalam kelas maupun forum yang lebih besar. Dalam diskusi, maka mahasiswa akan belajar berpikir kritis dan belajar mengasah pikirannya untuk tidak mengutip tanpa sumber referensi yang jelas dan tanpa pertanggung jawaban.

4) Memberikan penugasan di lapangan secara langsung seperti membuat laporan hasil obeservasi. Dengan penugasan tersebut, mahasiswa akan menuangkan hasil observasinya dilapangan kedalam tulisannya. Jadi mahasiswa tidak akan dengan mudah menjiplak atau mengcopy paste materi dari internet dan buku.

5) Mengajarkan kepada mahasiswa tentang parafhrase kalimat yang harus dilakukan untuk menghindari tindakan plagiasi. Dalam penulisan karya ilmiah mahasiswa dituntut untuk kreatif yaitu menciptakan ide baru dan karya baru yang bermanfaat. ${ }^{43}$ Ketika mahasiswa mengutip karya milik orang lain, hendaknya mengambil ide atau

${ }^{41}$ Makhfiyana dan Mudzakkir, Rasionalitas Plagiarisme dikalangan, h. 6.

${ }^{42}$ Wiguna, Metode Resitasi Berbasis, h. 106.

${ }^{43}$ Wiguna, h. 105.

Indonesian Journal of Islamic Education Studies (IJIES)

Volume 2, Nomor 1, Juni 2019 
gagasannya saja kemudian harus berpikir kreatif untuk memparafrasekan kalimat yang dikutip.

6) menghimbau kepada mahasiswa agar melakukan kutipan tidak langsung atas referensi yang dirujuk.

7) Mengharuskan mahasiswa memperbanyak pengambilan reverensi terutama dari buku cetak. Adanya motivasi dari dosen yaiu menjanjikan nilai yang bagus jika mahasiswa mengambil sumber materi dari buku cetak. ${ }^{44}$

8) Mewajibkan mahasiswa untuk mengikuti kelas online. Terdapat beberapa dosen yang membuka kelas online disetiap mata kuliahnya. Kelas online tersebut dapat berupa google class room dan edmodo. Dengan diadakannya kelas online maka mahasiswa diwajibkan mengunggah makah atau tugasnya berupa file yang kemudian dilakukan cek plagiasi oleh dosen.

9) Melakukan cek plagiasi online. Untuk tingkat makalah biasanya dosen melakukan cek plagiasi menggunakan plagiasrism checker.

10) Memberi tugas berupa review dengan tulis tangan. Menulis dengan tangan akan menuntut mahasiswa untuk berpikir meskipun materinya mengambil dari karya orang lain.

Dalam penulisan artikel ilmiah, masing-masing dosen pembimbing memiliki beberapa usaha untuk meminimalisasi perilaku plagiasi mahasiswa, di antaranya:

1) Pemahaman mengenai teknis penulisan artikel sesuai buku pedoman penulisan karya ilmiah serta penekanan untuk menghindari perilaku plagiasi

2) Menjalankan peraturan mengenai tindakan plagiasi sesuai buku pedoman penulisan karya ilmiah, diantaranya penetapan toleransi tindakan plagiasi $30 \%$.

3) Melakukan cek plagiasi secara online. Untuk tingkat artikel pengecekan plagiasi dilakukan dengan turnitin. Dengan adanya alat pendeteksi plagiasi semakin memudahkan dosen dalam meminimalisasi perilaku plagiasi mahasiswa.

4) Seleksi judul artikel. Diawal pembuatan artikel dosen pembimbing menyeleksi judul artikel beserta alasan mengapa memilih judul tersebut. Hal ini dilakukan untuk mendeteksi apakah judul tersebut benar-benar hasil pemikiran dari mahasiswa atau hanya sekedar menjiplak karya orang lain. Serta agar diawal pembuatan artikel mahasiswa sudah memiliki konsep yang jelas pada artikelnya.

5) Memberi referensi jurnal untuk mahasiswa. Dengan memberikan bantuan berupa reverensi yang sesuai dengan tugas yang diberikan, maka akan menambah semangat mahasiswa untuk menyelesaikan tugasnya sesuai dengan ketentuan yang ditetapkan.

6) Cek footnote dan daftar pustaka artikel.

Sama halnya dengan penulisan artikel ilmiah, dosen pembimbing skripsi juga memiliki peran yang sangat penting dalam keberhasilan penulisan skripsi mahasiswa, adapun beberapa usaha yang dilakukan oleh dosen pembimbing dalam meminimalisasi perilaku plagiasi mahasiswa yaitu:

1) Bimbingan sesuai prosedur yang ditetapkan. Dengan adanya bimbingan secara rutin dan teratur antara dosen pembimbing dan mahasiswa, maka dosen akan dengan

\footnotetext{
${ }^{44}$ Hidrawati, Budiati, Rohmad, Habituasi Plagiasrisme Tugas, h. 14. 
mudah unuk mengoreksi secara bertahap hasil penulisan skripsi mahasiswa, serta dapat melakukan revisi ulang jika memang terdeteksi melakukan plagiasi.

2) Pelatihan cara pengutipan sesuai buku baru pedoman penulisan karya tulis ilmiah. Hal ini dapat dilakukan diawal bimbingan atau disetiap pertemuan antara dosen pembimbing dengan mahasiswa, karena pada kenyataannya masih banyak mahasiswa yang belum memahami cara penulisan karya ilmiah yang baik dan benar sesuai buku pedoman penulisan karya ilmiah yang berlaku.

3) Bimbingan secara online yaitu dengan cara mahasiswa mengirimkan hasil tulisannya berupa soft file melalui email atau whatsapp untuk memudahkan dosen melakukan cek plagiasi.

4) Menetapkan batas toleransi plagiasi sesuai buku baru pedoman penulisan karya ilmiah yaitu $30 \%$ plagiasi dalam penulisan skripsi.

\section{Penutup}

Plagiasi yang terjadi dalam lingkup akademik terutama pada mahasiswa dalam penyelesaian tugas berupa karya ilmiah masih sering terjadi, hal ini didasari oleh beberapa faktor yang melatarbelakanginya. Dan disinilah pentingnya peran dosen dalam bersikap dan bertindak meminimalisasi perilaku plagiasi mahasiswa.

Beberapa sikap dan tindakan dosen dalam meminimalisasi perilaku plagiasi mahasiswa yaitu pertama, sosialisasi dosen kepada mahasiswa terkait plagiasi. Kedua, sebagai hukuman, mahasiswa diharuskan merevisi tulisannya, tetapi jika masih terdeteksi plagiasi, maka akan diberikan sanksi yang lebih berat yaitu pengurangan nilai. ketiga, pengumpulan tugas untuk cek plagiasi sesuai toleransi tingkat plagiasi yaitu $30 \%$.

Adapun usaha yang dilakukan oleh dosen dalam meminimalisasi perilaku plagiarisme mahasiswa diantaranya: memberikan pemahaman mengenai penulisan karya ilmiah dan pemahaman mengenai plagiasi, meningkatkan budaya baca mahasiswa, mengharuskan mahasiswa untuk aktif mengikuti forum diskusi, memberikan, mengajarkan kepada mahasiswa tentang parafhrase kalimat, menghimbau agar melakukan kutipan tidak langsung, memperbanyak pengambilan reverensi dari buku cetak, mengikuti kelas online melakukan cek plagiasi, memberi tugas berupa review dengan tulis tangan, seleksi judul artikel, memberi referensi jurnal untuk mahasiswa, bimbingan sesuai prosedur yang ditetapkan.

\section{Daftar Pustaka}

Arifin, Zainal dan Edi Nurhidin (Eds). Pedoman Penulisan Karya Tulis Ilmiah Makalah, Proposal, Dan Skripsi. Kediri : IAIT Press, 2018.

Ardiansyah, Agus. Dkk. "Ketidakjujuran Akademik dalam Pendidikan Tinggi”, (01 Juli 2018).

Arista, Riska Fajar dan Refri Handini Listyana, "Plagiarisme Dikalangan Mahasiswa", Paradigma, Vol.3, No. 1, (2015). 
Aziz, Lulu Andarini, Ana Irhandayaningsih, Aming Taufiq Kurniawan, "Upaya Perpustakaan dalam Mengurangi Plagiarisme Pada Karya Ilmiah Mahasiswa (Studi Kasus di UPT Perpustakaan UNIKA Soegijapranata”. Jurnal Ilmu Perpustakaan, Vol. 4, No. 3, (Juli 2015).

Hendrawan, Soetanto. "Memahami Plagiarisme Akademik". 2014, (memahami plagiarisme akademik- Universitas Brawijaya PDFppikid.ub.ac.id>uploads $>2014 / 10>$ PI..., diakses tanggal 15 Februari 2019).

Hidayah, Khoirul. "Tingkat Pemahaman Mahasiswa tentang Perlindungan Hak Cipta atas Karya Tulis”, Jurnal Syari'ah Dan Hukum, Vol. 5, No. 1, (Juni 2013).

Hidrawati, Dhanis, Atik Catur Budiati dan Zaini Rohmad, "Habituasi Plagiasrisme Tugas Kuliah dikalangan Mahasiswa FKIP UNS”, Jurnal Ilmiah Pendidikan SosiologiAntropologi, Vol.5, No. 2, (2015).

Indriati, Etty. Strategi Hindari Plagiarisme. Jakarta : PT gramedia pustaka utama, 2015.

Makhfiyana, Imroatullayyin dan Moh. Mudzakkir, "Rasionalitas Plagiarisme dikalangan Mahasiswa Fakultas Ilmu Sosial Unesa”, Paradigma, Vol. 1, No. 3, (2013).

Moleong, Lexy J. Metodologi Penelitian Kualitatif. Bandung: PT. Remaja Rosdakarya, 2017.

Mulyana. "Pencegahan Tindak Plagiarisme dalam Penulisan Skripsi", cakrawala pendidikan, No. 3, (mei 2010).

Noor, Juliansyah. Metodologi Penelitian Skripsi, Tesis, Disertasi \& Karya Ilmiah. Jakarta : Kencana, 2017.

Pradiansyah, Aditya. "Makna Plagiarisme bagi Mahasiswa Universitas Muhammadiyah". Surakarta: Skripsi, Jurusan Psikologi Universitas Muhammadiyah Surakarta, (2015).

Prihantini, Febrina Nafasati dan Dian Indudewi, "Kesadaran dan Perilaku Plagiarisme dikalangan Mahasiswa (Studi pada Mahasiswa Fakultas Ekonomi Jurusan Akutansi Universitas Semarang)", Jurnal Dinamika Sosial Budaya, Vol.18, 1 (Juni 2016).

Purnamasari, Desi. "Faktor-Faktor Yang Mempengaruhi Kecurangan Akademik Pada Mahasiswa",Educational Psychology Journal, (Online), Volume.2, No.1, 2013, (https://journal.unnes.ac.is/sju/index.php/epj/article/view/ 2581, diakses 15 desember 2018).

Sagoro, Endra Murti. "Pensinergian Mahasiswa, Dosen dan Lembaga dalam Pencegahan Kecurangan Akademik Mahasiswa Akuntansi", Jurnal Pendidikan Akuntansi Indonesia, Vol. XI, No. 2, (2013).

Santoso, Hari. "Pencegahan dan Penanggulangan Plagiarisme dalam Penulisan Karya Ilmiah dilingkungan Perpustakaan Perguruan Tinggi”, (28 Juli 2015). 
Soelistyo, Henry. Plagiarisme : Pelanggaran Hak Cipta Etika. Yogyakarta : kanisius, 2011.

Wiguna, I Made Arsa. "Metode Resitasi Berbasis TIK sebagai Upaya Penguatan Karakter Mahasiswa", Cetta : Jurnal Ilmu Pendidikan, Vol. 1, No. 2, (1 juni 2018). 